\title{
History teaching in Finnish general upper secondary schools: Objectives and practices
}

\author{
Matti Rautiainen, Eija Räikkönen, Anna Veijola and Simo Mikkonen - University \\ of Jyväskylä, Finland
}

\begin{abstract}
In Finland, the trend towards a new kind of history teaching emphasizing the understanding of historical knowledge and historical thinking skills began in the mid-1990s, when history teaching objectives were defined much more broadly in the curriculum than previously. In this article, we examine how, in over twenty years since the changes in curriculum objectives were made, general upper secondary school teachers have come to value the curriculum objectives of history teaching and how these have impacted on their teaching. The data for this article were collected by a semi-structured survey in 2016. Using counts, percentages, means, standard deviations and medians, a descriptive exploration was made of history teachers' perceptions of the essential objectives in teaching history and how often they were put into practice in related student activities. To investigate the balance between the objectives the teachers emphasized as the most essential and the teaching methods they actually used, we applied the Kruskal-Wallis test and the Friedman test. According to the results, what the teachers considered essential for teaching history did not correlate with their teaching methods. In addition, according to the results, this state of affairs is still undergoing change; old traditions and new objectives of history teaching are creating tensions. The results were interpreted in the light of the cultural viewpoints of Finnish teaching, the position of matriculation examinations in Finnish general upper secondary schools and the challenges the curriculum is setting for history teachers.
\end{abstract}

Keywords: Finland; general upper secondary schools, history teaching; objectives of teaching; quantitative research; teaching methods

\section{Introduction}

Although history has always been one of the core subjects in school, there has been continuous discussion of what should be taught and learned in school history classes. In Finland, history is taught in basic education from fourth or fifth grade to eighth grade, typically involving one or two 45-minute lessons a week. In primary school (where students studying history are aged 10 to 12 years), history is typically taught by a class teacher. In secondary school (for 13-16-year-old students), history is taught by a specialist history teacher. After this, there is a voluntary general upper secondary school, which has a course-based curriculum. The minimum number of courses in all subjects offered by a general upper secondary school is 75. Each course comprises 38 lessons, each lasting 45 minutes. The number of compulsory history courses that students take has been decreasing. The 2003 curriculum stipulated that every upper secondary school student needed to take four compulsory history courses, but in the current curriculum (2015), only three compulsory history courses remain. Each of 
these history courses is theme-based. The compulsory course themes are 'The human in environmental and societal change', 'International relations in the twentieth and twenty-first centuries' and 'History of independent Finland' (Finnish National Board of Education, 2016b).

In Finland, teachers are autonomous, independent and trusted professionals. There is no external assessment or any kind of formal teacher evaluation in Finland. Thus, teachers can choose their pedagogical solutions independently based on the curriculum. Both in basic education and in general upper secondary schools, the national curriculum defines and lists content that has to be studied. However, teachers are free to use their own pedagogical thinking and choose their teaching methods. The national core curriculum emphasizes that history teaching 'is based on the nature of history as a discipline, and its criteria for the formation of knowledge' (ibid.: 179). According to the national core curriculum for general upper secondary schools (Finnish National Board of Education, 2016b), attention should be paid to critical analysis and interpretation of information, and to diverse perspectives on different phenomena. Since autumn 2016, a new curriculum has been implemented in Finnish upper secondary schools. History curricula both in basic education and in upper secondary schools place even more emphasis on students' ability to reconstruct information about the past and to critically evaluate the information and understand the ambiguity and relativity of historical knowledge (Finnish National Board of Education, 2016a, 2016b).

To implement the curriculum in practice, teachers should understand history as a subject, where content knowledge and skills go hand in hand. This means that the objectives for teaching should be reflected in the classroom activities to implement them. In this article, we explore this balance using data collected via a survey of 151 Finnish upper secondary school history teachers in 2016.

\section{History in Finnish general upper secondary schools}

Why study history in school? In his famous essay, On the Advantage and Disadvantage of History for Life (originally published in 1874), Friedrich Nietzsche criticized historians for the way they taught history from a single, absolute viewpoint. Instead of this, Nietzsche thought that history has to offer learners something for themselves, for their life (Nietzsche, 1980). This tension has been one of the key questions among history teachers worldwide, especially since the 1970s, when, for example, the Schools Council History Project in England challenged the teaching of the 'great tradition' of a canon of historical information about the development of British national identity and patriotism, and turned history teaching towards objectives of critical thinking and an understanding of the nature of history (Schools History Project, 1976: 9-25; Cannadine et al., 2011: 160-2). In Finland, the trend towards a new kind of history teaching emphasizing an understanding of historical knowledge and historical thinking skills began in the mid-1990s, when objectives for history teaching were defined much more broadly in the new curriculum than previously (Opetushallitus, 1994).

Historical thinking is based on the question, 'How do we know what we know about the past?' (Seixas and Morton, 2013). Historical thinking skills consist of an ability to assess historical significance and how to analyse different kinds of sources, then to make valid interpretations based on them (for example, Nokes, 2013; VanSledright, 2010: 114; Lévesque, 2009: 140-68; Wineburg, 1991, 2001). In the contemporary national core curriculum for general upper secondary schools (Finnish National Board of Education, 2016b), the objectives are manifold. 
The Finnish national core curriculum emphasizes that the teaching and learning of history is based on the nature of history as a discipline. Attention should be paid to the basics of constructing knowledge of history, the critical evaluation of the validity and reliability of information, and the explanation of phenomena from multiple perspectives. Students familiarize themselves with the significance and possibilities of the individual as an actor, and reflect on the motives and factors underlying the actions of individuals and population groups in their historical contexts. The significance of human rights, equality and fairness, as well as the possibilities of democracy and international cooperation in solving the challenges of our time and the future, are emphasized in the teaching and learning. The history of Finland is examined against the background of world history (Finnish National Board of Education, 2016b: 179).

The objectives of the national core curriculum for general upper secondary schools, both 2003 and 2015 versions (Finnish National Board of Education, 2004 and 2016b), can be grouped into three main categories:

1. History content. For example, mastering the main developmental trends and the key historical processes, together with their backgrounds and consequences, in the history of Finland and the world.

2. Historical skills. For example, the ability to construct knowledge of the past using appropriate sources of information, evaluate it critically and understand its relativity and susceptibility to multiple interpretations.

3. Active, democratic citizenship. For example, the capability to form a world view in which human rights, equality and democracy are valued, and the ability to act as a responsible citizen promoting these values.

History teaching in Finland has had a strong connection to the process of nation building and national identity, from the 1860s and 1870s, when formal schooling for children started in the country, up to the 1970s. Finnish authors such as Johan Ludvig Runeberg and Zachris Topelius wrote a history for the people of Finland that became widely shared during the national awakening in the nineteenth century. Nationally oriented history was transferred to history books in the 1870s (Yrjö-Koskinen, 1873; Wallin, 1875) and became an integral part of teacher education. To a great extent, this approach remained unchanged until the 1960s, after which left-wing politicians and scholars began to question this tradition. They wanted to replace part of history courses with courses in social studies. They also stressed objectives such as peace and global education in history teaching. Tensions in basic education were stronger than in general upper secondary schools. For example, an experiment in Pirkkala municipality in 1973-5 became a subject of major controversy when teaching materials based on a Marxian interpretation of the history of Finland were implemented in primary schools. This raised an enormous, unprecedented public debate involving parliament. The experiment was terminated in 1975, and the debate around history teaching became more neutral in the late 1970s and 1980s (Leskinen, 2016). In the 1990s, as described above, the objectives of history teaching changed towards discipline-based literacy. At the same time, chronology-based history courses were replaced by themebased courses.

Changes in history teaching in the 1990s in Finland were closely related to changes in education. The autonomy of teachers, as well as that of schools, notably increased. The system controlling teaching materials and schools was abolished. There was a radical decrease in normative guidance through the curriculum in the national core curriculum for general upper secondary schools as of 1994. Further, new concepts and theories of learning encouraged learners' active role in learning processes and 
collaborative working (Valtonen and Rautiainen, 2019). In history education, new trends placed historical skills and the nature of history at the core of the objectives. Then, in the 2000s, active and democratic citizenship was introduced as the third main objective for history teaching. In other words, objectives in history teaching became radically broader and the nature of history teaching changed towards understanding the nature of history, and towards active citizenship.

However, the matriculation examination, which is the only national high-stakes test in Finland, directs pedagogical solutions in general upper secondary schools. It is a compulsory, national curriculum-based external examination, but history is one voluntary subject among many others. Since the choice of tests and the grades received are important when applying to a university, the matriculation examination is extremely important in general upper secondary schools. Although only 20 per cent of general upper secondary school students take the matriculation examination in history, teaching in upper secondary schools typically follows the skills and knowledge needed in tests. History matriculation tests, with an emphasis on remembering content knowledge and the skills needed to interpret brief sources in the context of historical periods, have remained mostly unchanged since 1995. Furthermore, the third main objective, active and democratic citizenship, has remained marginal compared with the other two objectives.

Overall, major changes have taken place during the past 25 years, especially in the curriculum. Nevertheless, have the changes had an effect on the everyday reality of classrooms in Finland? How do general upper secondary teachers view the objectives of the curriculum and practice in their work? In this article, we examine the degree to which general upper secondary school teachers value the objectives of history teaching and how they are teaching in classrooms.

\section{Methods}

\section{Participants and data collection}

The data for this article were based on a semi-structured survey conducted in November and December 2016. The survey was carried out electronically, and could be completed independently with a computer or a mobile device. We collected email addresses of all the history teachers who taught at the upper secondary school level in Finland in autumn 2016. Since comprehensive registers do not exist in Finland, we collected email addresses from the public web pages of schools. The link to the survey was sent out to all teachers for whom an email address was obtained. The total number of recipients was 776. A reminder was sent a few weeks later. After these survey rounds, 151 teachers (19.46 per cent of the initial sample) responded to the survey and gave permission to use their answers in this research. Of these respondents, 99 per cent had completed master's or higher-level studies. Almost all teachers (92 per cent) had studied history as their major, and all respondents had studied at least 60 ECTS (European Credit Transfer and Accumulation System) in history. Most teachers (72 per cent) had taught history in schools for more than ten years. Nearly all (98.67 per cent) had completed their pedagogical studies (60 ECTS). All in all, the informants were highly qualified teachers. The questionnaire consisted of 44 questions concerning, for example, teachers' backgrounds. This article uses only some of these questions, which will be considered in more detail later. 


\section{Data analyses}

The data analyses were conducted using SPSS 24 software (IBM Corporation, 2016). History teachers' perceptions of essential objectives in teaching history, and the frequency of using them in practice and in student-related activities in history teaching, were explored descriptively using counts, percentages, means, standard deviations and medians.

The balance between the objectives that the teachers described as the most essential and the teaching methods they used was investigated in two ways. First, the Kruskal-Wallis test was employed to compare teachers who chose different objectives as the most essential in their teaching in the frequency of using different kinds of working methods and student-related activities. The Kruskal-Wallis test is a non-parametric statistical test for comparing medians of two or more groups (Greene and D'Oliveira, 2006). Teaching methods (that is, three different working methods and two different student-related activities, as described later in more detail) were used as dependent variables in these analyses. The dependent variables were analysed separately, resulting in five different analyses. The same independent variable was used in all of these analyses. The independent variable was formed by dividing the teachers into groups according to the objective they identified as the most essential. Only objectives that were found to vary sufficiently on the basis of descriptive statistics were taken into account in the grouping. The Kruskal-Wallis test was chosen as the method of analysis as some of the dependent variables were measured with an ordinal scale (working methods), while others were interval scale variables (student-related activities), but these variables were skewed (Greene and D'Oliveira, 2006).

Second, frequencies of using different working methods were compared with each other via the Friedman test in order to find out whether the methods are used equally often in teaching. Similarly, the two student-related activities were compared via the Wilcoxon signed-rank test. Both analyses were conducted separately for each objective group (ibid.). The Friedman and Wilcoxon tests are non-parametric statistical tests that do not assume normality of the variables of interest. Furthermore, both of the tests can be employed with variables that have been measured with an ordinal scale. The Friedman test is used in our study to compare three or more sets of scores that come from the same participants (ibid.). In our study, these scores are the items measuring frequency of using different working methods. The Wilcoxon test is similar, but it can be used to compare only two sets of scores that come from the same participants (ibid.). Here, they are the two student-related activities.

\section{Results}

\section{Teachers' perceptions of the objectives of teaching history}

The survey enquired into the perceptions of the teachers regarding the most important objectives in teaching history. The survey included 14 ready-stated objectives, from which the teachers were asked to rank 5 objectives they considered most important. Table 1 presents the distributions of the teachers' rankings. Almost three-quarters of the teachers ranked objective 4, 'Understands contemporary times as the outcome of historical development, and a starting point for the future', among the five most essential objectives, and one-third of the teachers considered this objective the most essential one. Also, objective 10, 'Understanding the ambiguity and relativity of the past', was selected by most of the teachers, and over one-tenth of the teachers identified this objective as the most important. Objectives 1, 2 and 3 were each selected by about 
half of the teachers. Moreover, about one-tenth considered one of these objectives as the most essential in history teaching. In contrast, only a few of the teachers ranked objectives 6, 7 and 9 among the five most essential objectives, and only about 1-2 per cent of the teachers ranked one of these objectives as the most essential in teaching. Only objectives 1-4 and 10 will be used in further analyses as an adequate number of teachers had chosen one of these as the most essential objective in history teaching. Objectives 1-4 and 10 are closely linked with the categories of history content and historical skills, but not with active and democratic citizenship mentioned above.

Table 1: Teachers' $(N=151)$ perceptions of essential objectives in teaching history

\begin{tabular}{|c|c|c|c|c|c|c|c|c|c|}
\hline \multirow{2}{*}{\multicolumn{2}{|c|}{ Objective }} & \multicolumn{5}{|c|}{ Ranking of objectives } & \multicolumn{2}{|c|}{$\begin{array}{l}\text { Teachers } \\
\text { who } \\
\text { ranked the } \\
\text { objective }\end{array}$} & \multirow[t]{2}{*}{$\begin{array}{c}\text { Teachers who } \\
\text { ranked the } \\
\text { objective as the } \\
\text { most essential } \\
\%\end{array}$} \\
\hline & & 1st & 2nd & $3 r d$ & 4th & 5th & $N$ & $\%$ & \\
\hline 1 & $\begin{array}{l}\text { Understands different forms } \\
\text { of manifestation of culture, } \\
\text { as well as their diversity* }\end{array}$ & 15 & 19 & 12 & 14 & 14 & 74 & 49.01 & 9.93 \\
\hline 2 & $\begin{array}{l}\text { Commands the main lines } \\
\text { of Finnish and world history* }\end{array}$ & 16 & 18 & 14 & 2 & 23 & 73 & 48.34 & 10.60 \\
\hline 3 & $\begin{array}{l}\text { Masters the key historical } \\
\text { processes and can assess } \\
\text { their significance* }\end{array}$ & 12 & 19 & 18 & 12 & 7 & 68 & 45.03 & 7.95 \\
\hline 4 & $\begin{array}{l}\text { Understands contemporary } \\
\text { times as the outcome of } \\
\text { historical development, and } \\
\text { starting point for the future* }\end{array}$ & 50 & 18 & 20 & 15 & 8 & 111 & 73.51 & 33.11 \\
\hline 5 & $\begin{array}{l}\text { Manages to place the } \\
\text { contemporary time into a } \\
\text { historical continuum }\end{array}$ & 3 & 9 & 10 & 14 & 10 & 46 & 30.46 & 1.99 \\
\hline 6 & $\begin{array}{l}\text { Deepening of personal } \\
\text { historical cognition/ } \\
\text { consciousness }\end{array}$ & 2 & 4 & 4 & 9 & 5 & 24 & 15.89 & 1.32 \\
\hline 7 & Education for democracy & 5 & 1 & 7 & 5 & 7 & 25 & 16.56 & 3.31 \\
\hline 8 & $\begin{array}{l}\text { Cultivation of historical } \\
\text { empathy }\end{array}$ & 2 & 8 & 9 & 2 & 10 & 31 & 20.53 & 1.32 \\
\hline 9 & $\begin{array}{l}\text { Construction of knowledge } \\
\text { of the past by using relevant } \\
\text { sources }\end{array}$ & 4 & 7 & 4 & 9 & 4 & 28 & 18.54 & 2.65 \\
\hline 10 & $\begin{array}{l}\text { Understanding the } \\
\text { ambiguity and relativity of } \\
\text { the past* }\end{array}$ & 18 & 22 & 16 & 27 & 11 & 94 & 62.25 & 11.92 \\
\hline 11 & $\begin{array}{l}\text { Learn to use historical } \\
\text { knowledge in forming } \\
\text { justified arguments }\end{array}$ & 7 & 14 & 14 & 13 & 13 & 61 & 40.40 & 4.64 \\
\hline 12 & $\begin{array}{l}\text { Be able to critically assess } \\
\text { the uses of history in politics } \\
\text { and society }\end{array}$ & 4 & 1 & 10 & 15 & 13 & 43 & 28.48 & 2.65 \\
\hline
\end{tabular}




\begin{tabular}{|c|c|c|c|c|c|c|c|c|}
\hline \multirow[t]{2}{*}{ Objective } & \multicolumn{5}{|c|}{ Ranking of objectives } & \multicolumn{2}{|c|}{$\begin{array}{l}\text { Teachers } \\
\text { who } \\
\text { ranked the } \\
\text { objective }\end{array}$} & \multirow{2}{*}{$\begin{array}{c}\text { Teachers who } \\
\text { ranked the } \\
\text { objective as the } \\
\text { most essential } \\
\%\end{array}$} \\
\hline & 1st & 2nd & $3 r d$ & 4th & 5th & $N$ & $\%$ & \\
\hline $\begin{array}{l}13 \text { Learn to use historical know- } \\
\text { how to survey current and } \\
\text { future challenges }\end{array}$ & 4 & 7 & 7 & 9 & 11 & 38 & 25.17 & 2.65 \\
\hline $\begin{array}{l}14 \text { Learn to use historical know- } \\
\text { how to solve current and } \\
\text { future challenges }\end{array}$ & 9 & 4 & 6 & 5 & 15 & 39 & 25.83 & 5.96 \\
\hline
\end{tabular}

Note: *Objective was used in further analyses

\section{Working methods in relation to objectives}

The survey also included a question about the working methods that the teachers used in their teaching. The teachers were presented with five methods, and they were asked to respond on how often they used each method using a four-point scale $(1=$ not at all, 2 = sometimes, 3 = often, 4 = almost always). Table 2 presents frequency distributions for these working methods. Most of the teachers reported using the first three methods ('Tell about the issue at hand'; 'Tell about the issue at hand, but also use inclusive methods'; 'Use inclusive methods') often or almost always in their teaching. Visits and visitors were used less frequently, as about 90 per cent of the teachers reported using these working methods not at all or sometimes.

Table 2: Teachers' $(N=151)$ frequency of using working methods

\begin{tabular}{|c|c|c|c|c|c|c|c|c|c|}
\hline \multicolumn{2}{|c|}{ Working method } & \multicolumn{2}{|c|}{ Not at all } & \multicolumn{2}{|c|}{ Sometimes } & \multicolumn{2}{|c|}{ Often } & \multicolumn{2}{|c|}{$\begin{array}{l}\text { Almost } \\
\text { always }\end{array}$} \\
\hline & & $n$ & $\%$ & $n$ & $\%$ & $n$ & $\%$ & $n$ & $\%$ \\
\hline 1 & $\begin{array}{l}\text { Tell the students about the } \\
\text { issue at hand }\end{array}$ & 1 & 0.66 & 24 & 15.89 & 58 & 38.41 & 68 & 45.03 \\
\hline 2 & $\begin{array}{l}\text { Tell the students about the } \\
\text { issue at hand, but also use } \\
\text { inclusive methods (such as } \\
\text { ask questions and discuss } \\
\text { in between) }\end{array}$ & 1 & 0.66 & 9 & 5.96 & 54 & 35.76 & 87 & 57.62 \\
\hline 3 & $\begin{array}{l}\text { Use inclusive methods } \\
\text { (such as varied assignments } \\
\text { and group work) }\end{array}$ & 1 & 0.66 & 32 & 21.19 & 71 & 47.02 & 47 & 31.13 \\
\hline 4 & $\begin{array}{l}\text { Make visits with my classes } \\
\text { (e.g. museums, historical } \\
\text { sights/destinations) }\end{array}$ & 23 & 15.23 & 113 & 74.83 & 13 & 8.61 & 2 & 1.32 \\
\hline 5 & $\begin{array}{l}\text { My classes welcome } \\
\text { visitors (e.g. veterans) }\end{array}$ & 38 & 25.17 & 108 & 71.52 & 5 & 3.31 & 0 & 0 \\
\hline
\end{tabular}

Table 3 presents the means, standard deviations and medians of working methods $1-3$ by the most essential objectives (1-4 and 10). Comparison of the objective groups in the frequency of using each working method via the Kruskal-Wallis test revealed that the teachers who highlighted different most essential objectives did not differ statistically significantly from each other in the frequency of using working methods. 


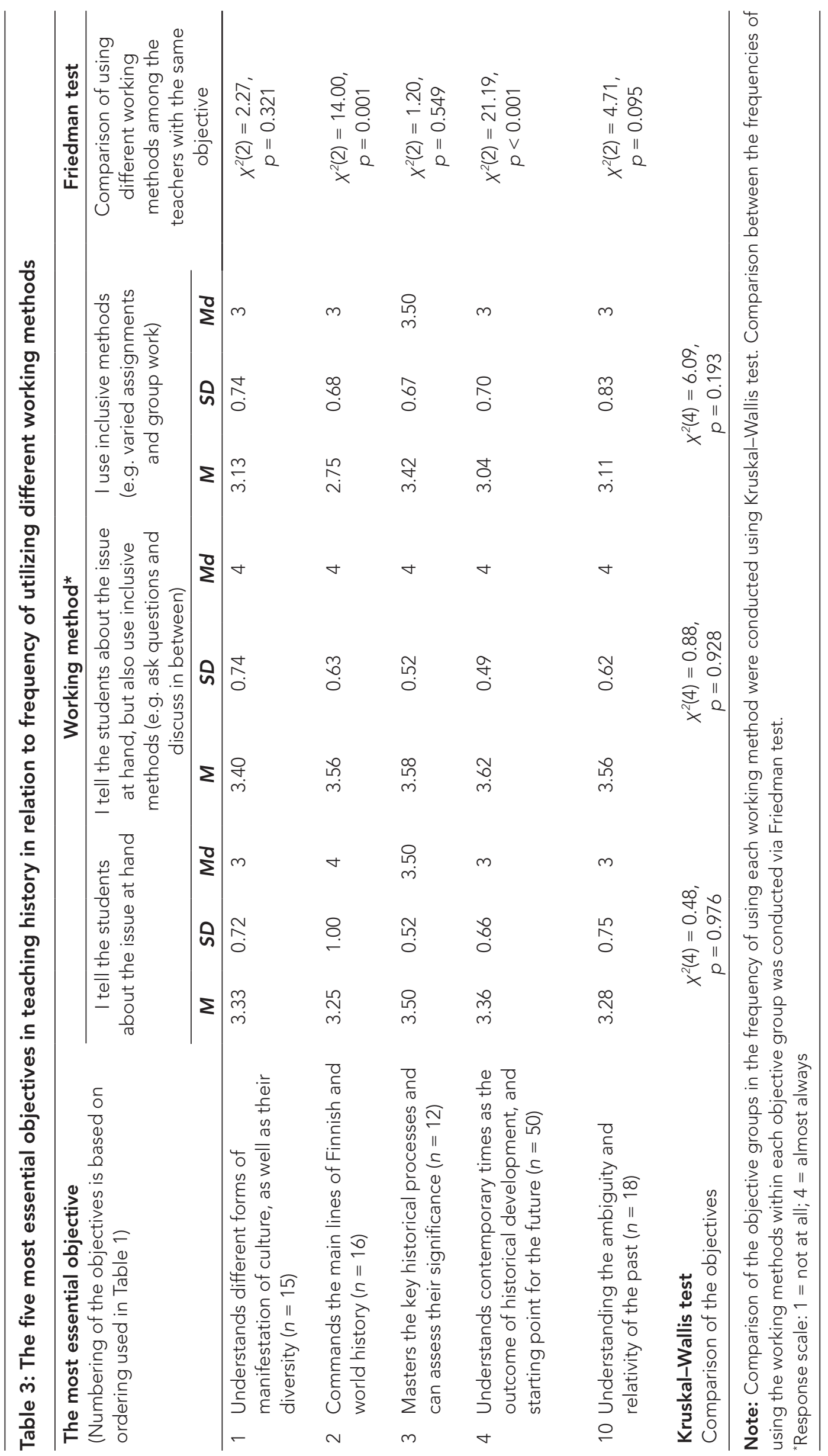


However, when comparing the three working methods with each other within each objective group, differences emerged. Results of the Friedman tests showed statistically significant differences between the frequencies of using working methods 2 and 3 in objective groups 2 and 4 (see Table 3). The teachers who reported either 'Concentrating on the main lines of Finnish and world history' or 'Understanding contemporary times as the outcome of historical development, and the starting point for the future' as the most essential objective in their teaching mentioned using method 2 ('I tell the students about the issue at hand, but also use inclusive methods') more often than method 3 ('I use inclusive methods'). Method 1 ('I tell the students about the issue at hand') was utilized as often as methods 2 and 3 within these objective groups. No statistically significant differences between the frequencies of using the three working methods were found within objective groups 1, 3 and 10. This suggests that the teachers who emphasized 'Understanding different forms of manifestation of culture, as well as their diversity', 'Mastering the key historical processes and assessment of their significance', or 'Understanding the ambiguity and relativity of the past' used the three working methods equally often.

\section{Student-related activities in relation to objectives}

The survey also looked into the frequencies of using student-related activities in history teaching. Ten activities were presented to the teachers: nine ready-stated activities and one open-ended activity option, 'Something else, what?'. The four-point response scale was: $1=$ not at all, 2 = sometimes, $3=$ often, $4=$ almost always. Frequencies of using these activities are presented in Table 4. Most activities were used either sometimes or often. The exception was activity 4, 'Students empathize with people who lived in the past (for example, through drama/pageant)', as over one-third of the teachers reported not using this activity at all in their teaching, while about three-fifths used the activity only sometimes. None of the teachers mentioned that they would use this method almost always.

\section{Table 4. Teachers' ( $N=151)$ frequency of using student-related activities}

\begin{tabular}{|c|c|c|c|c|c|c|c|c|c|}
\hline \multicolumn{2}{|r|}{ Student-related activities } & \multicolumn{2}{|c|}{ Not at all } & \multicolumn{2}{|c|}{ Sometimes } & \multicolumn{2}{|c|}{ Often } & \multicolumn{2}{|c|}{ Almost always } \\
\hline & & $n$ & $\%$ & $n$ & $\%$ & $n$ & $\%$ & $n$ & $\%$ \\
\hline 1 & $\begin{array}{l}\text { Students work with } \\
\text { documents that } \\
\text { necessitate interpretation }\end{array}$ & 3 & 1.99 & 59 & 39.07 & 68 & 45.03 & 21 & 13.91 \\
\hline 2 & $\begin{array}{l}\text { Students retrieve } \\
\text { information }\end{array}$ & 3 & 1.99 & 49 & 32.45 & 77 & 50.99 & 22 & 14.57 \\
\hline 3 & $\begin{array}{l}\text { Students do assignments } \\
\text { made by others (e.g. } \\
\text { teacher guides, other } \\
\text { teaching materials) }\end{array}$ & 13 & 8.61 & 58 & 38.41 & 63 & 41.72 & 17 & 11.26 \\
\hline 4 & $\begin{array}{l}\text { Students empathize with } \\
\text { people who lived in the } \\
\text { past (e.g. through drama/ } \\
\text { pageant) }\end{array}$ & 56 & 37.09 & 88 & 58.28 & 7 & 4.64 & 0 & 0 \\
\hline 5 & $\begin{array}{l}\text { Students read textbook/ } \\
\text { other literature }\end{array}$ & 4 & 2.65 & 58 & 38.41 & 66 & 43.71 & 23 & 15.23 \\
\hline 6 & $\begin{array}{l}\text { Students write essays/ } \\
\text { other writings }\end{array}$ & 4 & 2.65 & 89 & 58.94 & 55 & 36.42 & 3 & 1.99 \\
\hline
\end{tabular}




\begin{tabular}{|c|c|c|c|c|c|c|c|c|c|}
\hline \multicolumn{2}{|r|}{ Student-related activities } & \multicolumn{2}{|c|}{ Not at all } & \multicolumn{2}{|c|}{ Sometimes } & \multicolumn{2}{|c|}{ Often } & \multicolumn{2}{|c|}{ Almost always } \\
\hline & & $n$ & $\%$ & $n$ & $\%$ & $n$ & $\%$ & $n$ & $\%$ \\
\hline 7 & $\begin{array}{l}\text { Students discuss different } \\
\text { interpretations of history } \\
\text { and differences between } \\
\text { them }\end{array}$ & 12 & 7.95 & 82 & 54.30 & 45 & 29.80 & 12 & 7.95 \\
\hline 8 & $\begin{array}{l}\text { Students plan themselves } \\
\text { how they will study history }\end{array}$ & 55 & 36.42 & 87 & 57.62 & 9 & 5.96 & 0 & 0 \\
\hline 9 & $\begin{array}{l}\text { Students use materials } \\
\text { produced by other } \\
\text { students }\end{array}$ & 38 & 25.17 & 98 & 64.90 & 14 & 9.27 & 1 & 0.66 \\
\hline & Something else, what? & 5 & 3.31 & 1 & 0.66 & 1 & 0.66 & 0 & 0 \\
\hline
\end{tabular}

For further analyses, two composite scores were formed of the activities. The composite scores were computed as mean scores. The first one, 'Students as producers of historical knowledge', was composed of activities 1, 4 and 6-8 (see Table 3). The reliability score for this variable was 0.67 . The other score was labelled as 'Students as consumers of historical knowledge', and its reliability score was 0.54 .

Means, standard deviations and medians of the composite scores of studentrelated activities by the most essential objectives (1-4 and 10) are shown in Table 5. According to the Kruskal-Wallis test results, the teachers who highlighted different most essential objectives differed statistically significantly in the frequency of using activities in which the student is regarded as a consumer of knowledge. Pairwise comparisons of the teacher groups showed that the teachers who identified 'Mastery of the main lines of Finnish and world history' (objective 2) as the most essential objective reported less often using methods in which students were considered as consumers of historical knowledge, compared to the teachers who emphasized 'Mastering the key historical processes and assessing their significance' (objective 3 ) as the most essential objective in teaching history. No statistically significant differences were found between the teachers using student-related activities in which the students are regarded as producers of historical knowledge.

\section{Table 5: The five most essential objectives in teaching history in relation to frequency of utilizing student-related activities}

\begin{tabular}{|c|c|c|c|c|c|c|c|c|}
\hline \multirow{3}{*}{\multicolumn{2}{|c|}{$\begin{array}{l}\text { The most essential objective } \\
\text { (Numbering of the objectives } \\
\text { is based on ordering used in } \\
\text { Table 1) }\end{array}$}} & \multicolumn{6}{|c|}{ Student-related activity } & \multirow{3}{*}{$\begin{array}{c}\text { Wilcoxon test } \\
\text { Comparison of using } \\
\text { different activities } \\
\text { among the teachers } \\
\text { with the same } \\
\text { objective }\end{array}$} \\
\hline & & \multicolumn{3}{|c|}{$\begin{array}{c}\text { Students as } \\
\text { producers }\end{array}$} & \multicolumn{3}{|c|}{$\begin{array}{l}\text { Students as } \\
\text { consumers }\end{array}$} & \\
\hline & & $M$ & $S D$ & $M d$ & $M$ & $S D$ & Md & \\
\hline 1 & $\begin{array}{l}\text { Understands different forms } \\
\text { of manifestation of culture, } \\
\text { as well as their diversity } \\
(n=15)\end{array}$ & 2.13 & 0.38 & 2.20 & 2.43 & 0.36 & 2.50 & $Z=2.65, p=0.008$ \\
\hline 2 & $\begin{array}{l}\text { Commands the main lines of } \\
\text { Finnish and world history } \\
(n=16)\end{array}$ & 2.09 & 0.33 & 2.20 & 2.23 & 0.31 & 2.25 & $Z=1.71, p=0.088$ \\
\hline
\end{tabular}




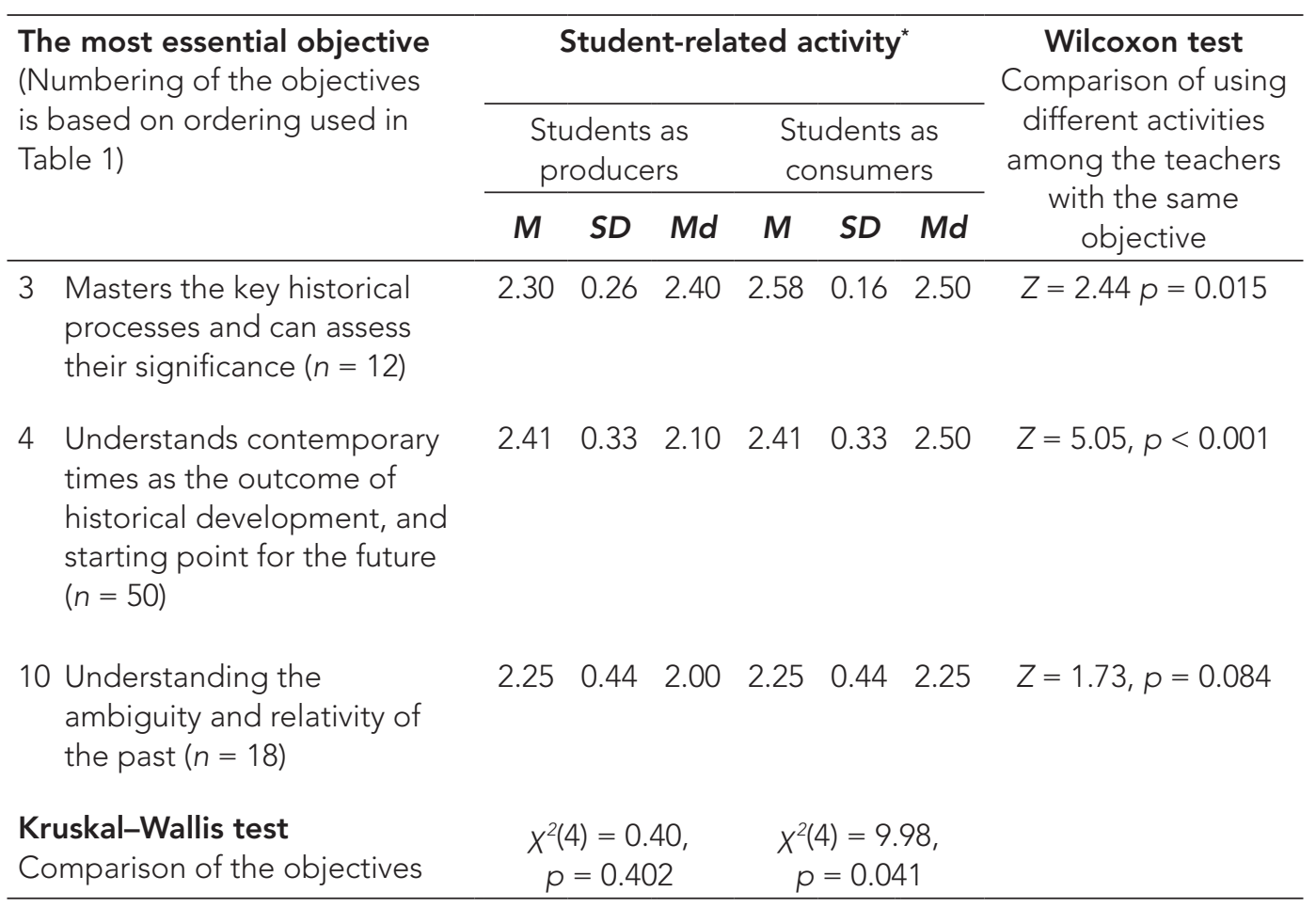

Note: Comparison of the objective groups in the frequency of using each activity was conducted using Kruskal-Wallis test. Comparison between the frequencies of using student-related activities within each objective group was conducted using Wilcoxon test.

*Response scale: 1 = not at all; 4 = almost always

Also differences in the frequencies of use between the two activities were found. Namely, Wilcoxon's tests showed that the frequencies of using student-related activities differed in objective groups 1, 3, and 4 (see Table 5). The teachers who emphasized 'Understanding different forms of manifestation of culture, as well as their diversity', 'Mastering the key historical processes and assessment of their significance' or 'Understanding contemporary times as the outcome of historical development, and a starting point for the future' as the most essential objective reported more often using activities in which the student was regarded as a consumer of historical knowledge compared to activities in which the student was considered a producer of knowledge. No statistically significant differences between the frequencies of using the two student-related activities were found within objective groups 1, 3 and 10 . That is, both student-related activities were used equally often by the teachers who emphasized one of these objectives as the most essential one.

\section{Discussion}

The planning of teaching is based on questions of why (aim), what (content) and how (method). Although different pedagogical theories highlight different aims, contents and methods for teaching, they all stress the importance of aims, and methods through which the aims can be achieved. Olson (1976) argues that different methods lead to different learning results, and this question has also been at the core of history teaching since the 1970s (see, for example, Reeves, 1980). As Vygotsky argues, conceptual understanding is possible when studying is based on the learner's activity, not on the teacher's explanations (Gredler, 2012). Three major aims of history teaching in Finnish upper secondary schools are history content, historical skills, and active, democratic 
citizenship. They all include cognitive process dimensions from all six dimensions, from remembering to creating (see, for example, Anderson and Krathwohl, 2001), but when compared to each other, skills and democratic citizenship are more global educational objectives, and learning them takes more time than the instructional and sometimes very narrow objectives of learning the content of history (ibid.: 17). In practice, learning historical skills and democratic citizenship have more dimensions, and those objectives usually require activity, for which we use the concept 'producer'. Producing means that students actively produce historical knowledge, for example via different texts, videos or artefacts. In contrast, a 'consumer' is one who passively consumes interpretations of history produced by others. This can be a teacher's presentation, or reading a book.

We expected that there would be a stronger connection between the aims of teaching and classroom activities. In other words, teachers who focus on content (such as main lines of development of Finnish and world history) would more often use teacher-centred methods, and those who stress historical skills and active, democratic citizenship would more often use student-centred methods. However, according to our results, what the teachers considered essential for teaching history was not associated with their teaching methods. How is this possible?

The curriculum for history teaching in Finnish general upper secondary schools is stratified, containing many objectives in three compulsory courses. In the 1980s, there were six compulsory history courses in general upper secondary schools and the national core curriculum emphasized content, divided between the history of Finland and world history (Kouluhallitus, 1985). Currently, students in general upper secondary schools study three compulsory history courses, and even if there are fewer compulsory content areas than thirty years ago, there is still a lot to grasp. Because remembering historical content is a necessity for good grades in the matriculation examination, it still guides the teaching and pedagogical choices that teachers make. Since 1994, curricula for general upper secondary schools (1994, 2003 and 2015) have stressed historical skills and, in the 2000s, active and democratic citizenship as well. The current curriculum is historically stratified, and the question is whether there are too many objectives for the time available, for teachers as well as learners? Finnish teachers are strongly committed to their work, and try to deal with different aspects of the curriculum in their work. Are teachers mixing methods and aims in their history teaching because there are so many objectives, necessitating the use of different approaches?

Subcultures among different subject teacher groups are strong, based on tradition, values and other historically constructed characteristics (Grossman and Stodolsky, 1995). Juha Varto (2005), a Finnish philosopher, has described school as an old cellar full of things from different eras of our life. Similarly, schools have sediments from different eras of history. Some of the sediments are old, and teachers have become blind to their origins and merely repeat the routines and cultural features adapted from the previous generation of teachers. In Finland, the history teachers' subculture and the concepts of good history teaching remained largely uniform until the 1980s. The changes made in the curriculum since 1994 have been slowly transferred to classroom practices. Despite these changes, teaching materials have stuck to the content-based tradition. In addition, in-service teacher training for history teachers concerning new objectives in the curriculum was non-existent until the 2010s. In the 2010s, curriculum and classroom practices began to converge. Furthermore, teaching materials as well as in-service training are offering new approaches to history teaching. In addition, discussion among history teachers concerning aims and practices among professionals has increased. 


\section{Conclusion}

During the past 25 years, history teaching in general upper secondary schools in Finland has undergone change. Historical skills and active, democratic citizenship have moved into the core of the curricula. In addition, student-centred methods have been central to classroom practices since the 1990s. According to these trends, history teaching should have changed considerably towards student-centred teaching, emphasizing especially historical skills. However, according to our results, the state of affairs is still undergoing change; old traditions and new objectives of history teaching are creating tensions within the field. In this situation, teachers are still confused by the new objectives in history teaching, even though they have been implemented since 1994.

The matriculation examination controls teaching and learning in general upper secondary schools in Finland. Now, the matriculation test in history is a compromise between history teaching emphasizing remembering content and historical skills stressing the interpretation of individual, short written sources, films or pictures related to questions in the matriculation test. Nevertheless, the historical skills needed in the test are less important than is a good knowledge of the historical content and processes. We argue that the importance of historical skills, as well as active, democratic citizenship, would be greater in classroom practices if they played a stronger role in the matriculation test.

The objectives of Finnish history teaching in general upper secondary schools are challenging. In particular, the teaching of historical skills as well as active, democratic citizenship requires student-centred methods, where the complexity of historical knowledge becomes visible. We have implemented several in-service training courses for history teachers, where historical skills and active, democratic citizenship have been under study. Any new approach takes time because changing theoretical perspectives and practices involves questioning professional identity and understanding of the meaning of history teaching. In this process, no teacher should be alone, but should be supported by long-term in-service training and collaborative and collegial peer support.

We propose that interaction between history teachers should be an essential part of teachers' profession and practices. Currently, teachers in Finland typically work as individuals. In smaller general upper secondary schools, there is typically a single history teacher. History teachers have their own national association (HYOL), and it supports networking between history teachers by offering different media for sharing, such as good practices developed by history teachers in their own work. However, only a few teachers are active in the association, sharing their own thoughts and developmental work with others. This situation reflects the general ethos of Finnish teachers' individual agency. Although collaboration between teachers has been encouraged since the 1990s, an individual working culture is still prevalent in schools.

We also need more research to deepen the understanding of history teaching in general upper secondary schools. This survey serves as a good basis, but there is a need for teacher interviews and classroom observation. General upper secondary schools are currently undergoing change. The Finnish National Agency for Education is preparing a new national curriculum for general upper secondary schools, and it will be implemented from August 2021. According to our results, presented in this article, tensions exist between the objectives of the curriculum and the methods that teachers are using. An important continuing research question is: Why is a normative level of education (curriculum) not visible in the everyday activities in classrooms in general upper secondary schools? 
Due to the relatively small sample size $(N=151)$, our study may have suffered from limited statistical power. This is especially relevant in our comparisons of the five different objective groups in relation to the frequency of using certain working methods and student-related activities. It may be that we were not able to obtain statistically significant differences between the objective groups, as most of them were small. Therefore, studies with larger samples are needed in the future to confirm our results.

\section{Notes on the contributors}

Matti Rautiainen is a senior lecturer in pedagogy of history and social sciences in the Department of Teacher Education at the University of Jyväskylä, Finland. His research interests are pedagogy of history, education for democracy and teacher education. His latest books are: Yee, B., Sliwka, A. and Rautiainenn, M. (eds) (2018) Engaging Adolescent Learners: International perspectives on curriculum, pedagogy and practice, Cham: Palgrave Macmillan, and Raiker, A. and Rautiainen (eds) (2017) Educating for Democracy in England and Finland: Principles and culture, London: Routledge.

Eija Räikkönen is an adjunct professor and senior lecturer in the Faculty of Education and Psychology, University of Jyväskylä, Finland. Her research interests and teaching include quantitative research methods.

Anna Veijola works as a postdoctoral researcher in the Department of History and Ethnology at the University of Jyväskylä, Finland. Her research interests are historical thinking and historical literacy and enquiry-based learning in history. Currently she is working on the project Engaging in Disciplinary Thinking: Historical Literacy Practices in Finnish General Upper Secondary Schools, funded by the Academy of Finland.

Simo Mikkonen is Academy of Finland Research Fellow in the Department of History and Ethnology, University of Jyväskylä, Finland. He specializes in twentieth-century Russian and Eastern European history, cultural and artistic diplomacy, and émigrés. He has published extensively on cultural, international and transnational East-West connections, particularly from the Soviet perspective.

\section{References}

Anderson, L.W. and Krathwohl, D.R. (eds) (2001) A Taxonomy for Learning, Teaching, and Assessing: A revision of Bloom's Taxonomy of Educational Objectives. New York: Longman.

Cannadine, D., Keating, J. and Sheldon, N. (2011) The Right Kind of History: Teaching the past in twentieth-century England. Basingstoke: Palgrave Macmillan.

Finnish National Board of Education (2004) National Core Curriculum for General Upper Secondary Schools 2003. Helsinki: Finnish National Board of Education.

Finnish National Board of Education (2016a) National Core Curriculum for Basic Education 2014. Helsinki: Finnish National Board of Education.

Finnish National Board of Education (2016b) National Core Curriculum for General Upper Secondary Schools 2015. Helsinki: Finnish National Board of Education.

Gredler, M.E. (2012) 'Understanding Vygotsky for the classroom: Is it too late?'. Educational Psychology Review, 24 (1), 113-31.

Greene, J. and D'Oliveira, M. (2006) Learning to Use Statistical Tests in Psychology. 3rd ed. Maidenhead: Open University Press.

Grossman, P.L. and Stodolsky, S.S. (1995) 'Content as context: The role of school subjects in secondary school teaching'. Educational Researcher, 24 (8), 5-23.

IBM Corporation (2016) IBM SPSS Statistics for Windows, Version 24.0. Armonk, NY: IBM Corporation.

Kouluhallitus (1985) Lukion opetussuunnitelman perusteet 1985. Helsinki: Kouluhallitus. 
Leskinen, J. (2016) Kohti sosialismia! Pirkkalan peruskoulun marxilainen kokeilu 1973-75. Helsinki: Siltala.

Lévesque, S. (2009) Thinking Historically: Educating students for the twenty-first century. Toronto: University of Toronto Press.

Nietzsche, F. (1980) On the Advantage and Disadvantage of History for Life. Trans. Preuss, P. Indianapolis: Hackett Publishing Company.

Nokes, J.D. (2013) Building Students' Historical Literacies: Learning to read and reason with historical texts and evidence. New York: Routledge.

Olson, D.R. (1976) 'Notes on a cognitive theory of instruction'. In Klahr, D. (ed.) Cognition and Instruction. Hillsdale, NJ: Lawrence Erlbaum Associates, 117-20.

Opetushallitus (1994) Lukion opetussuunnitelman perusteet 1994. Helsinki: Opetushallitus.

Reeves, M. (1980) Why History? London: Longman.

Schools History Project (1976) A New Look at History: Schools history 13-16 project. Edinburgh: Homes McDougall. Online. www.schoolshistoryproject.co.uk/wp-content/uploads/2015/12/ NewLookAtHistory.pdf (accessed 5 August 2019).

Seixas, P. and Morton, T. (2013) The Big Six Historical Thinking Concepts. Toronto: Nelson Education.

Valtonen, H. and Rautiainen, M. (2019) 'A land of education? The history of Finnish education from the 1850 s to the present'. Article manuscript (submitted).

VanSledright, B.A. (2010) 'What does it mean to think historically... and how do you teach it?'. In Parker, W.C. (ed.) Social Studies Today: Research and practice. New York: Routledge, 113-20.

Varto, J. (2005) 'Koulun syytä etsimässä'. In Kiilakoski, T., Tomperi, T. and Vuorikoski, M. (eds) Kenen kasvatus? Kriittinen pedagogiikka ja toisinkasvatuksen mahdollisuus. Tampere: Vastapaino, 197-216.

Wallin, O. (1875) Suomen historia kansakouluja varten. Helsinki: Weilin ja Göös.

Wineburg, S.S. (1991) 'Historical problem solving: A study of the cognitive processes used in the evaluation of documentary and pictorial evidence'. Journal of Educational Psychology, 83 (1), 73-87.

Wineburg, S. (2001) Historical Thinking and Other Unnatural Acts: Charting the future of teaching the past. Philadelphia: Temple University Press.

Yrjö-Koskinen, Y.S. (1873) Oppikirja Suomen kansan historiassa. Helsinki: Suomalaisen Kirjallisuuden Seura. 